\title{
PENINGKATAN KESELAMATAN PASIEN SELAMA MASIH BERADA DI RUMAH SAKIT
}

\author{
Agnes Jessica Lubis
}

Jessikaagnes8@gmail.com

\section{Latar belakang}

Keselamatan pasien kini telah menjadi isu global tidak dipungkiri pula juga untuk rumah sakit. Oleh karena itu, keselamatan pasien merupakan prioritas yang utama untuk dilaksanakan dan hal itu terkait dengan terjadinya Insiden Keselamatan Pasien (IKP) di rumah sakit. Menurut Depkes RI (2008) dalam Panduan Nasional Keselamatan Pasien Rumah Sakit, tindakan pertama program keselamatan pasien di rumah sakit adalah membangun budaya keselamatan pasien ataupun menumbuhkan kesadaran pada seluruh karyawan kesehatan akan pentingnya nilai keselamatan di rumah sakit. Jadi, Untuk meningkatkan mutu pelayanan keselamatan pasien di tingkat unit maka harus dilakukan upaya perubahan budaya keselamatan pasien di seluruh unit diRumah Sakit.

Keselamatan pasien merupakan suatu prinsip dasar dalam pelayanan kesehatan. Keselamatan pasien (patient safety)di rumah sakit ialah suatu sistem dimana rumah sakit membuat asuhan pasien lebih aman, Menurut Departemen kesehatan Republik Indonesia (2008). Sistem tersebut meliputi bagian bagian dari assessmen risiko, identifikasi dan pengelolaan hal yang berhubungan dengan risiko pasien, pelaporan dan analisis insiden, kemampuan belajar dari insiden dan tindaklanjutnya serta implementasi solusi untuk meminimalkan timbulnya risiko. Sistem tersebut diharapkan dapat mencegah terjadinya cedera yang disebabkan oleh kesalahan akibat melaksanakan suatu tindakan atau tidak melakukan tindakan yang seharusnya dilakukan.

Keselamatan pasien dalam pelayanan kesehatan mendapatkan banyak perhatian sejak Institute of Medicine (IOM) pada tahun 2000 menerbitkan laporan yang berjudul "To Err is Human : Building a Safer Health System" yang mengemukakan Angka Kematian Akibat Kejadian tidak diharapkan (KTD) pada pasien rawat inap di seluruh Amerika berjumlah 44.000-98.000 orang pertahun. Dengan menggunakan estimasi yang lebih rendah, lebih banyak orang mati akibat kesalahan medis dalam setahun dibandingkan kecelakaan jalan raya, kanker payudara, atau AIDS. 
Laporan ini disusul dengan publikasi WHO pada tahun 2004 yang menemukan KTD dengan rentang 3,2-16,6\% dari penelitian di berbagai negara (Depkes RI, 2008). Di Indonesia Laporan Insiden Keselamatan Pasien menemukan adanya pelaporan kasus KTD (14,41\%) dan Kejadian nyaris cedera $(18,53 \%)$ yang disebabkan karena proses atau prosedur klinik $(9,26 \%)$, medikasi $(9,26 \%)$, dan Pasien jatuh $(5,15 \%)$. (KKP RS, 2011)

Budaya keselamatan pasien merupakan faktor penting dalam upaya untuk mengurangi resiko yang merugikan di rumah sakit dan meningkatkan keselamatan pasien. Penelitian yang dilakukan Wang dkk (2014) ini bertujuan untuk mendeskripsikan persepsi perawat tentang budaya keselamatan pasien dan frekuensi resiko yang merugikan, dan menguji hubungan antara keduanya.

Maka dari itu kesaran tentang budaya keselamatan pasien masih perlu ditingkatkan kembali. Baik dengan memberikan pelatihan-pelatihan dari yang terkecil hingga pelatihan pelatihan yang terbesar dan mengupdate pengetahuan tentang keselamatan pasien.

Motivasi untuk melaporkan jika ada insiden keselamatan pasien juga perlu ditingkatkan, karena laporan dapat menjadi penaganan dini terhadap insiden keselamatan pasien di masa yang akan datang serta mencegah insiden yang sama untuk terjadi kembali agar tidak bertambahnya korban dalam kesalahan insiden yang terjadi. Sebenarnya perawat tidak harus takut untuk melaporkannya hanya karena itu bukan bagian dari tugasnya.

\section{Metode}

Metode ini digunakan secara faktual dengan merujuk pada referensi referensi yang dapat dipercaya seperti contohnya ialah jurnal jurnal, e-book, serta buku teks . Dengan menggabungkan referensi referensi yang faktual keselamatan passion maka penulis berharap artikel ini dapat membantu orang orang yang membutuhkan informasi tentang Peningkatan keselamatan pasien selama masih berada diRumah Sakit. 


\section{Hasil}

Patient Safety ataupun Keselamatan Pasien merupakan hal yang jauh lebih penting dari pada sekedar efisiensi pelayanan. Perilaku seorang perawat dengan kemampuan yang dimiliki perawat sangat berperan penting dalam pelaksanaan keselamatan pasien saat berada di Rumah Sakit. Perilaku yang tidak aman, lupa, kurangnya perhatian/motivasi, kecerobohan, tidak teliti dan kemampuan yang tidak memperdulikan dan menjaga keselamatan pasien berisiko untuk terjadinya kesalahan kesalahan yang akan mengakibatkan cedera pada pasien, berupa Near Miss (Kejadian Nyaris Cedera/KNC) atau Adverse Event (Kejadian Tidak Diharapkan/KTD).

Banyak terjadinya kejadian tidak diharapkan bisa disebabkan oleh berbagai macam hal yang dilakukan dari berbagai macam profesi yang bekerja di Rumah Sakit. Contohnya kesalahan diagnosis, kejadian kesalahan tes laboratorium atau XRay, dan kesalahan pemberian obat (medication error),serta kesalahan sistem komunikasi (Cahyono, 2008). Ancaman dan kesalahan ini terjadi di rumah sakit karena terdapat begitu banyaknya macam obat, banyaknya hasil tes dan prosedur, serta banyak alat alat dengan teknologinya masing masing, bermacam jenis tenaga profesi dan non profesi yang siap memberikan pelayanan pasien 24 jam tanpa henti.

Keberagaman dan kerutinan pelayanan tersebut apabila tidak dikelola dengan baik dan benar maka dapat terjadi Kejadian Tidak Diharapkan (KTD) (Depkes, 2008, p.17)

Pengurangan kesalahan dapat dicapai dengan memodifikasi perilaku. Perawat harus melibatkan kognitif, afektif dan tindakan yang mengutamakan keselamatan pasien. Menurut World Health Organization (WHO) 2014, Keselamatan pasien merupakan masalah kesehatan masyarakat global yang serius.

Menurut Bawelle, 2013 secara keseluruhan program patient safety sudah diterapkan, namun masalah dilapangan merujuk pada konsep patient safety, karena walaupun sudah pernah mengikuti sosialisasi, tetapi masih ada pasien cedera, resiko jatuh, resiko salah pengobatan, pendelegasian yang tidak akurat saat oforan pasien yang mengakibatkan keselamatan pasien menjadi kurang maksimal. Hal tersebut merupakan bagian dari menganggap bahwasannya hal hal kecil tidak akan mengalami hal hal seperti KTD ataupun KNC. Maka dari itu, kesadaran dari petugas dirumah sakit sendiri sangatlah dibutuhkan dengan kemampuan kemampuan baik secara ilmu maupun secara tindakan. 


\section{Pembahasan}

Meningkatkan pelayanan kesehatan yang salah satunya dengan melalui sasaran keselamatan pasien. Sasaran keselamatan pasien yang dimaksud dalam akreditasi rumah sakit adalah Sasaran Keselamatan Pasien (SSP) yang terdiri dari

1. Sasaran I adalah Ketepatan Identifikasi Pasien,

2. Sasaran II adalah Peningkatan komunikasi yang efektif,

3. Sasaran III adalah Peningkatan keamanan obat yang perlu diwaspadai,

4. Sasaran IV adalah Kepastian tepat lokasi, tepat prosedur, dan tepat pasien operasi,

5. Sasaran IV adalah Pengurangan risiko infeksi terkait pelayanan kesehatan,

6. Sasaran VI adalah Pengurangan risiko pasien jatuh

(Direktoran BUN, Kemenkes, dan KARS, 2011). Keselamatan pasien masih perlu dibudayakan, menurut NHS (2004) bahwa budaya keselamatan pasien yang perlu dikembangkan adalah melalui pengembangan pengkajian yang meliputi senior management visibility dan komitmen keselamatan, komunikasi diantara manajer dan staf, sikap untuk melaporkan kejadian, kesalahan dan punishment.

Peningkatan mutu pelayanan dirumah sakit sangat diperlukan sesuai dengan sejalan meningkatnya pengetahuan masyarakat akan haknya sebagai penerima jasa pelayanan sehingga masyarakat mampu memilih berbagai alternatif pelayanan yang bermutu yang dapat memberikan kepuasan bagi dirinya maupun keluarganya. Rumah sakit akan berkompetensi baik secara nasional maupun internasional ataupun secara global, sehingga upaya peningkatan mutu pelayanan dirumah sakit sangatlah menjadi prioritas. Selain itu, dalam rangka mendukung upaya rujukan dan pelayanan puskesmas maka pelayanan rumah sakit haruslah bermutu dan berkualitas, oleh karena itu rumah sakit perlu terus berupaya meningkatkan mutu pelayanannya.

Peningkatan mutu pelayanan rumah sakit, tidak dapat dikatakan mudah karena terkait dengan banyak nya hal hal ataupun problem. Tinggi rendahnya mutu tersebut sangat dipengaruhi sumber daya yang dimiliki rumah sakit, interaksi pemanfaatan sumber daya rumah sakit yang digerakkan melalui proses dan prosedur tertentu menghasilkan jasa atau pelayanan. Mutu pelayanan rumah sakit harus dapat dipertanggungjawabkan karena menyangkut banyak hal, salah satunya adalah keselamatan pasien yang menjadi sasaran utama. 
Keselamatan pasien di rumah sakit adalah suatu sistem dimana rumah sakit akan membuat asuhan pasien lebih aman dan nyaman. Sistem tersebut meliputi penilaian risiko, identifikasi dan pengelolaan hal yang berhubungan dengan risiko pasien saat berada di rumah sakit, pelaporan dan analisis insiden, kemampuan belajar dari insiden dan tindakan lanjutannya serta implementasi solusi untuk meminimalkan timbulnya risiko.

Keselamatan pasien salah satu langkah kritis pertama untuk memperbaiki kualitas pelayanan. Tak terlepass dari pada laporan Institute of Medicine (IOM) di Amerika daerah Utah dan Colorado ditemukan kejadian tidak diinginkan sebesar 2,9\% dimana 6,6\% meninggal dunia, sedangkan di New York sebesar 3,7\% angka kejadian tidak diinginkan dengan angka kematian 13,6\%.(5) Angka kematian akibat kejadian yang tidak diharapkan di bagian rawat inap di seluruh Amerika berkisar 44.000-98.000 per tahunnya.

Di RSUD Pamekasan diberitakan bahwa terjadi kecelakaan pasien jatuh yang diduga karena kesalahan yang dilakukan perawat, kejadian ini berawal ketika perawat meminta pasien untuk pindah ranjang karena akan dibersihkan, setelah menyuruh pindah tanpa bertanya apakah pasien sanggup berpindah sendiri atau butuh bantuan kemudian perawat pergi keluar ruangan dan ketika kembali didapati pasien tersebut telah jatuh dan mengalami patah lengan kiri.

Variabel budaya dalam keselamatan pasien pada dimensi keterbukaan komunikasi yang responden dengan jumlah 69,61\% menilai tidak adanya kewenangan bebas mempertanyakan keputusan yang diambil pimpinan. Dimensi serah terima serta transisi pasien dari unit ke unit lainnya sebesar $72,55 \%$ dari total responden menilai bahwa sering tidak tersampaikan informasi penting saat pertukaran shift. Pada dimensi penyusunan staf, 85,29\% dari total responden atau tenaga kesehatan menyatakan bahwa jumlah tenaga kesehatan masih kurang. Dimensi tindakan promotif keselamatan pasien oleh Manajer atau Supervisor sebesar 67,65\% dari total responden menyatakan bahwa adanya kekhawatiran bahwa setiap kesalahan tenaga kesehatan akan masuk dalam penilaian kinerjanya.

Karakteristik individu yang terdiri dari factor usia, masa kerja dan status pekerjaan memberikan pengaruh negative terhadap Insiden Keselamatan Pasien sedangkan status menikah memberikan pengaruh positive terhadap Insiden Keselamatan Pasien. Variabel budaya keselamatan pasien memberikan pengaruh negative terhadap Insiden Keselamatan Pasien di Rumah Sakit Umum 
Daerah Banten. Analisa multivariate yaitu semua variable dilakukan uji bersama-sama secara simultan maka faktor yang paling dominan pengaruhnya adalah faktor usia tenaga kesehatan yang cukup berpengaruh.

Angood (2007) Dewi (2012) mengungkapkan bahwa berdasarkan hasil dari kajian data bahwa penyebab utama KTD di rumah sakit adalah komunikasi. Alvarado (2006) mengungkapkan bahwa tidak akuratnya informasi dapat menimbulkan dampak yang cukup serius pada pasien, hampir 70\% kejadian sentinel (kejadian yang mengakibatkan kematian atau cedera serius saat berada di rumah sakit) disebabkan karena buruknya komunikasi. Komunikasi terhadap berbagai informasi mengenai perkembangan pasien antar profesi kesehatan di rumah sakit merupakan komponen yang fundamental dalam perawatan pasien (Riesenberg,2010). pertukaran informasi pada saat pergantian shift yang disebut dengan handover memiliki tujuan untuk menyampaikan informasi dari setiap pergantian shift serta memastikan efektifitas dan keamanan dalam perawatan pasien. Informasi terkait dengan keadaan klinis pasien, kebutuhan pasien, keadaan personal pasien, sampai pada faktor sosial pasien. Perawat harus datang minimal 15 menit lebih awal untuk mengikuti pergantian shift sehingga proses handover dapat berjalan lancar (McCLoughen et al., 2008 dalam Scovell, 2010).

Membangun budaya keselamatan pasien merupakan elemen penting untuk meningkatkan keselamatan pasien dan kualitas pelayanan. Penilaian budaya keselamatan pasien di rumah sakit dapat dilakukan dengan menilai dimensi-dimensi yang terkait dengan budaya keselamatan pasien. Salah satu survey untuk menilai budaya keselamatan pasien adalah dari AHRQ.Ada 12 dimensi yang dinilai dalam survey AHRQ,4 diantaranya merupakan dimensi out come. (AHRQ,2004).

Banyak keluarga pasien yang tidak dapat menerima kesalahan dari petugas medis sehingga ada kejadian beberapa keluarga membawa kejalur hukum sehingga tenga medis tersebut menjadi tersangka atau bahkan bisa masuk dalam tahanan sel. Frekuensi pelaporan kejadian yang kurang ataupun kesalahan kesalahan dalam tindakan merupakan hambatan staf untuk melakukan pembelajaran dari insiden yang telah terjadi.Laporan merupakan awal proses pembelajaran untuk mencegah kejadian yang sama terulang kembali. Agar segala kejadian atau insiden dapat terdokumentasi dengan baik, sehingga dapat dilakukan analisa serta tindakan korektif atau preventif selanjutnya (KKPRS, 2008) 


\section{Penutup}

a.kesimpulan

Keselamatan pasien merupakan suatu prinsip dasar dalam pelayanan kesehatan. Keselamatan pasien (patient safety)di rumah sakit ialah suatu sistem dimana rumah sakit membuat asuhan pasien lebih aman, Menurut Departemen kesehatan Republik Indonesia (2008). Sistem tersebut meliputi bagian bagian dari assessmen risiko, identifikasi dan pengelolaan hal yang berhubungan dengan risiko pasien, pelaporan dan analisis insiden, kemampuan belajar dari insiden dan tindaklanjutnya serta implementasi solusi untuk meminimalkan timbulnya risiko. Sistem tersebut diharapkan dapat mencegah terjadinya cedera yang disebabkan oleh kesalahan akibat melaksanakan suatu tindakan atau tidak melakukan tindakan yang seharusnya dilakukan.

b. saran

untuk mahasiswa keperawatan maupun yang sudah profesi diharapakan untuk belajar memahami setiap kegiatan secara professional agar tidak terjadinya hal hal yang tidak diinginkan yang merugikan diri sendiri ataupun pihak rumah sakit. Adapun untuk meningkatkan keselamatan pasien saat berada di rumah sakit dengan cara Meningkatkan pengetahuan semua pihak di rumah sakit tentang keselamatan pasien melalui upaya pembelajaran berkelanjutan

Daftar pustaka

- Najihah. 2018. BUDAYA KESELAMATAN PASIEN DAN INSIDEN KESELAMATAN PASIEN DI RUMAH SAKIT: LITERATURE REVIEW. Journal of Islamic Nursing Vol. 3 No. 1.

- Lombogia, Angelita., dkk. 2016. Hubungan Perilaku dengan Kemampuan Perawat dalam Melaksanakan Keselamatan Pasien (Patient Safety) di Ruang Akut

- Yusuf, Muhammad. 2017. Penerapan Patien Safety diRuang Rawat Inap Rumah Sakit Umum Daerah Dr. Zainoel Abidin. Jurnal Ilmu Keperawatan vol.5 No.1.hal 1-2. 
- $\quad$ Budiono, S., Sarwiyata, T. W., \& Alamsyah, A. (2014). Pelaksanaan Program Manajemen Pasien dengan Risiko Jatuh di Rumah Sakit. Jurnal Kedokteran Brawijaya, 28(1), 78-83.

- Insani, T. H. N., dan Sundari, Sri. 2018. Analisis Pelaksanaan Keselamatan Pasien Oleh Perawat. Journal of Health Studies, vol.2. No.1

- triwibowo cecep,Juli 2016)Jurnal Keperawatan Soedirman (The Soedirman Journal of Nursing), Volume 11, No.2.

- $\quad$ arrum diah, 2015.ENGETAHUAN TENAGA KESEHATAN DALAM SASARAN KESELAMATAN PASIEN DI RUMAH SAKIT SUMATERA UTARA Idea Nursing Journal Vol. VI No. 2 ISSN : 2087-2879

- yasmi yulia,februari 2018 faktor faktor yang berhubungan dengan budaya karya bhakti pratiwi bogor tahun 2015keselamatan pasien dir umah sakit, volume 4 nomor 2

- Permenkes Menteri Kesehatan RI Nomor 11 Tahun 2017 Tentang Keselamatan Pasien.

- Mudayana, A.,A. (2015). Pelaksanaan Patient Safety Oleh Perawat di RS PKU Muhammadiyah Yogyakarta. Jurnal Kesehatan Samodra Ilmu. Vol. 6, No. 2.

- Simamora, R. H. (2018). Buku ajar keselamatan pasien melalui timbang terima pasien berbasis komunikasi efektif: SBAR. Medan: USUpress.

- Simamora, R. H. (2020). Learning of Patient Identification in Patient Safety Programs Through Clinical Preceptor Models. Medico Legal Update, 20(3), 553-556. 